\title{
MENGUKUR KEMAMPUAN BERPIKIR REFLEKTIF MATEMATIS MAHASISWA PADA MATERI DIFERENSIASI DAN INTEGRASI NUMERIK
}

\author{
Hedi Budiman \\ Pendidikan Matematika, FKIP, Universitas Suryakancana \\ hedi@unsur.ac.id
}

\begin{tabular}{l|l} 
Penerimaan : 17 Juli 2018 & Diterima: 1 Juni 2019
\end{tabular}

\begin{abstract}
ABSTRAK
Mata kuliah metode numerik merupakan salah satu mata kuliah yang dapat meningkatkan kemampuan berpikir reflektif. Dengan semakin pesatnya perkembangan teknologi, pada mata kuliah ini mahasiswa memerlukan perangkat teknologi untuk penyelesaian masalah matematis. Metode numerik adalah teknik-teknik yang digunakan untuk memformulasikan masalah matematis agar dapat dipecahkan dengan operasi perhitungan. Penelitian ini bertujuan untuk mengukur kemampuan berpikir reflektif matematis mahasiswa pada mata kuliah metode numerik sub pembahasan diferensiasi dan integrasi numerik. Sampel pada penelitian ini adalah seluruh mahasiswa tingkat 3 pendidikan matematika berjumlah 60 orang. Penelitian ini menggunakan metode deskritif. Hasil penelitian menunjukkan rata-rata kemampuan berpikir reflektif matematis mahasiswa calon guru pada materi diferensiasi dan integrasi numerik termasuk kategori baik, ratarata kemampuan berpikir reflektif matematis mahasiswa per indikator menunjukkan kategori sangat baik untuk dua indikator, kategori baik pada 1 indikator, dan kategori cukup pada 1 indikator, dan sikap mahasiswa positif terhadap materi diferensiasi numerik dan integrasi numerik.
\end{abstract}

Kata Kunci: berpikir reflektif, metode numerik, diferensiasi, integrasi

\begin{abstract}
The subject of numerical method is one of the subject that can improve the ability of reflective thinking. With the rapid development of technology, students need technological tools for solving mathematical problems, in this subject. Numerical methods are techniques used to formulate mathematical problems in order to be solved by computational operations. This study aims to measure students' mathematical reflective thinking in numerical method sub-courses of differentiation and numerical integration. The research sample were 60 mathematics education students'. This research used descriptive method. The results showed that the average of mathematical reflective thinking students' were good in the differentiation and numerical integration materials, the students' mathematical reflective thinking per category indicator was very good for two indicators, good category for one indicator, enough category for one indicator, and student attitudes was possitive toward numerical differentiation and numerical integration.
\end{abstract}

Keyword: Reflective thinking, Numerical Method, Differentiation, Integration 


\section{PENDAHULUAN}

Reformasi pendidikan mendorong lingkungan belajar pada pembelajaran lebih baik dan menciptakan pandangan yang berbeda tentang pengajaran dan pembelajaran. Peranan guru yang selalu berusaha mengembangkan diri menjadi dominan dalam meningkatkan kualitas siswa dalam memahami materi yang diberikan. Mahasiswa calon guru matematika selain menguasai materi matematika juga dituntut untuk mampu mengajarkan dan mendorong kemampuan berpikir matematis siswa. Salah satu yang perlu dimiliki mahasiswa calon guru adalah kemampuan berpikir reflektif. Berpikir reflektif sangat penting untuk perbaikan dalam pelaksanaan pengajaran. Menurut Dohn (2011), kemampuan reflektif ini semakin dilihat sebagai faktor penting dalam pengelolaan pembelajaran, dan peningkatan kompetensi. Reflektif melibatkan banyak keterampilan yang kompleks.

Berpikir reflektif adalah proses yang mendasari semua bentuk kompetensi pengajaran profesional yang tinggi (Bright, 2003). Berpikir reflektif dapat menjadi bermakna jika pemahaman yang diperoleh berasal dari refleksi yang digunakan untuk mempengaruhi perubahan diri (Adam, 2002). Upaya pemahaman dan peningkatan pengajaran seorang guru, harus dimulai dari refleksi atas pengalaman sendiri (Zeichner \& Liston, 2010). Individu harus mengkaji secara kritis apa yang sudah dilakukannya. Jika konsep refleksi tidak dipergunakan untuk melakukan pengkajian, maka akan terjadi kesalahan persepsi dalam pengajaran (Ash dan Clayton, 2004). Seorang guru berperan penting dalam mendorong berpikir matematik siswa. Guru juga memiliki tanggung jawab untuk mendorong keputusan siswa untuk lepas dari keraguan pada pelaksanaan pembelajaran (Dinkelman, 2000). Guru perlu mengevaluasi pencapaian siswa dalam kemampuan berpikirnya, termasuk tanggung jawabnya untuk melatih kemampuan melakukan refleksi di kalangan siswa sehingga dapat bekerja efektif dalam kehidupan di masa depannya (Takona, 2002). Kemampuan berpikir reflektif mahasiswa calon guru perlu di latih dan ditingkatkan.

Mata kuliah metode numerik merupakan salah satu mata kuliah yang dapat meningkatkan kemampuan berpikir reflektif. Dengan semakin pesatnya perkembangan teknologi, mata kuliah ini diperlukan mahasiswa untuk penyelesaian matematis menggunakan perangkat teknologi. Metode numerik adalah teknik-teknik yang digunakan untuk memformulasikan masalah matematis agar dapat dipecahkan dengan operasi 
perhitungan. Dengan mempelajari metode numerik diharapkan mahasiswa: (a) mampu menangani sistem persamaan besar, ketaklinieran dan geometri yang rumit, yang dalam masalah rekayasa tidak mungkin dipecahkan secara analitis; (b) mengetahui secara singkat dan jelas teori matematika yang mendasari paket program; (c) mampu merancang program sendiri sesuai permasalahan yang dihadapi pada masalah rekayasa; (d) menangani galat (error) suatu nilai hampiran (aproksimasi) dari masalah rekayasa yang merupakan bagian dari paket program yang bersekala besar; (e) menyediakan sarana memperkuat pengertian matematika mahasiswa. Karena salah satu kegunaannya adalah menyederhanakan matematika yang lebih tinggi menjadi operasi-operasi matematika yang mendasar.

Metode numerik berbeda dengan metode analitik. Metode analitik merupakan metode sejati karena memberikan solusi sejati atau solusi yang sesungguhnya, yaitu solusi yang memiliki galat atau error sama dengan nol. Di sisi lain, metode analitik memiliki keterbatasan pada saat menyelesaikan persoalan yang melibatkan bentuk dan proses yang rumit. Peranan metode numerik terlihat pada penyelesaian persoalan yang rumit. Proses penyelesaian perhitungan menggunakan solusi hampiran (approximation), yang ditentukan dengan besarnya error atau galat. Proses perhitungan persoalan yang rumit dapat disederhanakan dengan metoda numerik melalui operasi aritmatika biasa seperti tambah, kurang, kali dan bagi. Persoalan seperti pada gambar di bawah ini, dapat diselesaikan dengan operasi aritmatika biasa.
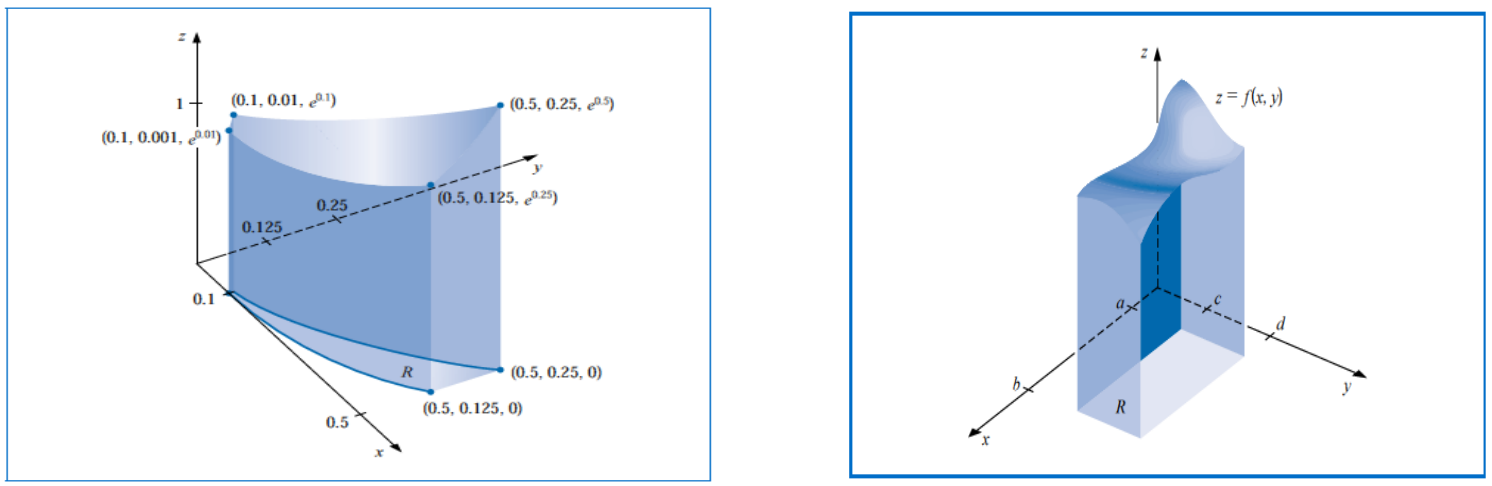

(Burden \& Faires , 2011)

Gambar 1. Menghitung Volume Benda Padat Gambar 2. Multiple Integral dengan Integrasi Lipat Dua Simpson Integral 
Materi diferensiasi dan integrasi numerik berkaitan dengan materi diferensial dan integral pada mata kuliah kalkulus yang sudah diikuti mahasiswa. Dengan dasar yang sudah dimiliki, mahasiswa cenderung lebih mudah untuk memahami konsep diferensiasi dan integrasi numerik. Persoalan diferensiasi numerik adalah menentukan hampiran (approximation) turunan fungsi $f$ yang diberikan dalam bentuk tabel. Seringkali fungsi $f(x)$ tidak diketahui secara eksplisit, tetapi hanya diketahui beberapa titik data saja. Pendekatan dengan metode analitik tidak bisa dilakukan, tetapi dapat diselesaikan dengan metode numerik. Pada integrasi numerik, perhitungan dilakukan pada integral tentu:

$$
I=\int_{a}^{b} f(x) d x
$$

Dalam hal ini $a$ dan $b$ adalah batas-batas integrasi, dan $f$ adalah fungsi yang dapat diberikan secara eksplisit dalam bentuk persamaan atau secara empirik dalam bentuk tabel nilai (Munir, 2010).

Diferensiasi numerik membahas pendekatan perhitungan dengan hampiran beda maju (forward difference approximation), hampiran beda mundur (backward difference approximation), hampiran beda pusat (central difference approximation). dan penggunaan Ekstrapolasi Richardson. Sedangkan integrasi numerik membahas: (a) Metode Pias yang terdiri dari kaidah segiempat, kaidah Trapesium, dan kaidah titik tengah; (b) Metode Newton-Cotes yang terdiri dari kaidah trapesium, kaidah Simpson; (c) Singularitas; (d) Ekstrapolasi: ekstrapolasi Richardson, metode Romberg, ekstrapolasi Aitken; (e) Integrasi Ganda; (f) Kuadratus Gauss (Munir, 2010).

\section{METODOLOGI PENELITIAN}

Penelitian ini merupakan penelitian deskriptif untuk mengukur kemampuan berpikir reflektif mahasiswa calon guru pada materi diferensiasi numerik dan integral numerik. Penelitian deskriptif adalah penelitian untuk mendeskripsikan atau menggambarkan realitas yang ada. Pada prinsipnya, penelitian deskriptif tidak bertujuan membentuk hipotesis atau pengembangan teori. Sampel pada penelitian ni adalah seluruh mahasiswa tingkat 3 pendidikan matematika berjumlah 50 orang.

Instrumen yang digunakan pada penelitian ini adalah tes tertulis yang berbentuk essay yang dibuat oleh peneliti. Tes essay merupakan item format yang memerlukan 
penjelasan secara terstruktur dalam beberapa paragrap. Karakteristik dari tes essay adalah umumnya berisi lebih dari satu pertanyaan, dijawab dengan tulisan, memerlukan jawaban yang cukup panjang, dan memerlukan keseriusan berpikir (Kubiszyn dan Borich, 2003).

Persentase kemampuan berpikir reflektif matematis mahasiswa yang ditunjukkan dalam tiap indikator menggunakan rumus sebagai berikut:

$$
P_{i}=\frac{\bar{s}}{s_{i}} \times 100 \%
$$

Keterangan:

$P_{\tilde{i}}=$ Persentase hasil kemampuan berpikir reflektif matematis perindikator

$\bar{s}=$ Skor rata-rata siswa per indikator

$s_{i}=$ Skor ideal indikator dimaksud

Klasifikasi tingkat kemampuan berpikir reflektif matematis mahasiswa berdasarkan hasil tes, menggunakan:

$$
P_{i}=\frac{n_{i}}{N} \times 100 \%
$$

$P_{\bar{i}}=$ Persentase siswa pada setiap kemampuan berpikir reflektif matematis

$n_{i}=$ Banyaknya siswa pada setiap kemampuan berpikir reflektif matematis

$N$ = Jumlah total siswa

\section{HASIL DAN PEMBAHASAN}

Penilaian hasil kemampuan berpikir reflektif mahasiswa berdasarkan ketentuan nilai yang berlaku di FKIP Universitas Suryakancana, yaitu:

\section{Tabel 1. Skor dan Interval Nilai}

\begin{tabular}{ccc}
\hline Skor Mentah & Interval Nilai & Huruf Mutu \\
\hline $\mathbf{8 5}-\mathbf{1 0 0}$ & $3,40-4,00$ & $\mathrm{~A}$ \\
\hline $\mathbf{7 0}-\mathbf{8 4}$ & $2,80-3,39$ & $\mathrm{~B}$ \\
\hline $\mathbf{6 0}-\mathbf{6 9}$ & $2,40-2,79$ & $\mathrm{C}$ \\
\hline $\mathbf{5 0}-\mathbf{5 9}$ & $0,99-2,39$ & $\mathrm{D}$ \\
\hline $\mathbf{0}-\mathbf{4 9}$ & $0,00-0,99$ & $\mathrm{E}$ \\
\hline
\end{tabular}


Tabel 2. Deskripsi Data Hasil Tes

\begin{tabular}{lccc}
\hline \multirow{2}{*}{ Data tes } & \multicolumn{2}{c}{ Nilai } & Keseluruhan \\
\cline { 2 - 4 } & Kelas A & Kelas B & Nilai \\
\hline Nilai maksimum & 98 & 98 & 98 \\
\hline Nilai Minimum & 54 & 58 & 54 \\
\hline Rata-rata & 79.73 & 83.75 & 81.66 \\
\hline Median & 81 & 84.00 & 82.00 \\
\hline Modus & 90 & 93 & 82 \\
\hline Varian & 162.28 & 119.24 & 142.88 \\
\hline Standar Deviasi & 12.74 & 10.92 & 11.95 \\
\hline
\end{tabular}

Dari Tabel 2 menunjukkan walaupun rata-rata nilai pencapaian kemampuan berpikir reflektif matematis kelas B lebih tinggi dari kelas A, tetapi masih termasuk skor mentah kategori nilai B yaitu 70-84. Artinya kemampuan berpikir reflektif matematis mahasiswa kelas A dan B sebanding. Dari standar deviasi memperlihatkan hasil pencapaian kelas A lebih menyebar dibandingkan kelas B.

Tabel 3. Data Kemampuan Berpikir Reflektif Matematis Mahasiswa

\begin{tabular}{ccccccc}
\hline \multirow{2}{*}{ Interval } & \multicolumn{2}{c}{ Frekuensi } & \multicolumn{2}{c}{ Persentase } & \multicolumn{2}{c}{ Keseluruhan } \\
\cline { 2 - 7 } & A & B & A & B & Frekuensi & Persentase \\
\hline $\mathbf{8 5}$-100 & 11 & 12 & $42.3 \%$ & $50.0 \%$ & 23 & $46.0 \%$ \\
\hline $\mathbf{7 0}-\mathbf{8 4}$ & 9 & 8 & $34.6 \%$ & $33.3 \%$ & 17 & $34.0 \%$ \\
\hline $\mathbf{6 0}-\mathbf{6 9}$ & 4 & 3 & $15.4 \%$ & $12.5 \%$ & 7 & $14.0 \%$ \\
\hline $\mathbf{5 0}-\mathbf{5 9}$ & 2 & 1 & $7.7 \%$ & $4.2 \%$ & 3 & $6.0 \%$ \\
\hline Total & 26 & 24 & $100.0 \%$ & $100.0 \%$ & 50 & $100.0 \%$ \\
\hline
\end{tabular}

Dari Tabel 3, memperlihatkan bahwa hasil persentase pencapaian kemampuan berpikir reflektif matematis mahasiswa dengan kategori nilai A yaitu 85 - 100, kelas B (50 $\%$ ) lebih tinggi dari kelas A (42,3\%). Kategori nilai B yaitu $70-84$, kelas A (34.6\%) lebih tinggi dari kelas B (33.3\%), kategori nilai C yaitu 60 - 69, kelas B (12.5\%) lebih rendah dari kelas B (15.4\%), dan kategori nilai D, yaitu 50 - 59, kelas B (4.2\%) lebih rendah dari kelas A (7.7\%). Secara keseluruhan pencapaian kemampuan kemampuan berpikir reflektif matematis mahasiswa dengan kategori nilai A yaitu 85 - 100 sebanyak 23 orang (46\%), kategori nilai B yaitu 70 - 84 sebanyak 17 orang (34\%), kategori nilai C yaitu $60-69$ sebanyak 7 orang (14\%), dan kategori nilai D yaitu 50-59 sebanyak 3 orang (6\%). 
Pencapaian ini memperlihatkan rata-rata kemampuan berpikir reflektif matematis mahasiswa termasuk kategori baik.

Untuk mengukur kemampuan berpikir reflektif matematis lebih rinci, perlu dijelaskan berdasarkan indikatornya, seperti pada tabel 4 di bawah. Pada indikator mengidentifikasi konsep matematika yang terlibat dan menentukan cara penyelesaian masalah, yang tekait nomor soal 1 (a) dan 1 (b), meminta para mahasiswa menjawab soal terkait data yang ditampilkan di tabel dengan cara tertentu. Mahasiswa harus mengetahui rumus matematika dari pertanyaan tersebut. Hasil kemampuan pencapaian mahasiswa ratarata 91,8\% yang termasuk kategori sangat baik, artinya sebagian besar mahasiswa dapat mengerjakan soal-soal tersebut dengan benar. Rata-rata pencapaian ini memperlihatkan para mahasiswa mampu mengidentifikasi konsep dan menentukan cara penyelesaian masalah. Pada soal nomor 1(b) dan 1(c), mahasiswa diminta menjawab dengan mengembangkan data yang tercantum di tabel. Cara menjawab mahasiswa dengan menarik analogi dari soal 1(a) dan 1(b). Hasil kemampuan pencapaian mahasiswa rata-rata 90,1\% yang termasuk kategori sangat baik, artinya sebagian besar mahasiswa dapat mengerjakan soal-soal tersebut dengan benar. Rata-rata pencapaian ini memperlihatkan para mahasiswa mampu menarik analogi dari masalah sebelumnya dan mengembangkannya dalam penyelesaian masalah.

Pada soal nomor 2 (a) dan 2 (b), mahasiswa diminta untuk mengembangkan data pada tabel berdasarkan gambar peta, menentukan nilainya, dan menentukan rumus yang digunakan. Mahasiswa harus mampu menerapkan rumus yang sesuai dengan pertanyaan dimaksud. Hasil kemampuan pencapaian mahasiswa rata-rata $80.4 \%$ yang termasuk kategori baik, artinya sebagian besar mahasiswa dapat mengerjakan soal-soal tersebut dengan benar. Rata-rata pencapaian ini memperlihatkan para mahasiswa mampu mengembangkan ide untuk memecahkan masalah dengan cara mengumpulkan data yang dibutuhkan dan menentukan rumus matematika yang digunakan.

Tabel 4. Persentase Kemampuan Berpikir Kritis Matematis Mahasiswa Per Indikator

\begin{tabular}{lcccc}
\hline \multicolumn{1}{c}{ Indikator } & $\begin{array}{c}\text { Nomor } \\
\text { Soal }\end{array}$ & $\begin{array}{c}\text { Rata-Rata } \\
\text { Skor } \\
\text { Indikator }\end{array}$ & $\begin{array}{c}\text { Skor Ideal } \\
\text { Indikator }\end{array}$ & $\begin{array}{c}\text { Persentase } \\
\text { Per } \\
\text { Indikator }\end{array}$ \\
\hline $\begin{array}{l}\text { Mengidentifikasi konsep } \\
\text { matematika yang terlibat } \\
\text { dan menentukan cara }\end{array}$ & 1 (a) dan (b) & 7.34 & 8 & $91.8 \%$ \\
\hline
\end{tabular}




\begin{tabular}{|c|c|c|c|c|}
\hline penyelesaian masalah & & & & \\
\hline $\begin{array}{l}\text { Menarik analogi dari } \\
\text { masalah sebelumnya dan } \\
\text { mengembangkannya } \\
\text { dalam penyelesaian } \\
\text { masalah }\end{array}$ & 1(c) dan (d) & 7.21 & 8 & $90.1 \%$ \\
\hline $\begin{array}{l}\text { Mengembangkan ide } \\
\text { untuk memecahkan } \\
\text { masalah dengan cara } \\
\text { mengumpulkan data yang } \\
\text { dibutuhkan dan } \\
\text { menentukan rumus } \\
\text { matematika yang } \\
\text { digunakan }\end{array}$ & 2 (a) dan (b) & 6.43 & 8 & $80.4 \%$ \\
\hline $\begin{array}{l}\text { Menguji solusi } \\
\text { pemecahan masalah dan } \\
\text { menggunakannya sebagai } \\
\text { bahan pertimbangan } \\
\text { membuat kesimpulan }\end{array}$ & 3 (a) dan (b) & 5.34 & 8 & $66.8 \%$ \\
\hline
\end{tabular}

Pada soal nomor 3 (a) dan 3 (b), mahasiswa diminta untuk membuat tabel sendiri berdasarkan gambar yang ada. Apakah pada bentuk benda seperti itu, volume pada bagian II selalu sama dengan volume bagian IV. Mahasiswa harus mampu menentukan nilai, menentukan rumus yang digunakan, dan membuat kesimpulan dari volume benda tersebut. Hasil kemampuan pencapaian mahasiswa rata-rata 66.8\% yang termasuk kategori cukup, artinya sebagian besar mahasiswa dapat mengerjakan soal-soal tersebut dengan benar. Rata-rata pencapaian ini memperlihatkan para mahasiswa mampu menguji solusi pemecahan masalah dan menggunakannya sebagai bahan pertimbangan membuat kesimpulan.

Tabel 5. Respon Mahasiswa Materi Diferensiasi dan Integrasi Numerik

\begin{tabular}{lcccccccccc}
\hline \multirow{2}{*}{ Kategori } & \multicolumn{8}{c}{ Jumlah Respon terhadap Pernyataan (\%) } \\
\cline { 2 - 13 } & 1 & 2 & 3 & 4 & 9 & 13 & 15 & 16 & 18 & 20 \\
\cline { 2 - 13 } & + & + & - & + & - & + & - & + & - & + \\
\hline Sangat Sering & 24 & 20 & 10 & 36 & 2 & 16 & 6 & 24 & 6 & 28 \\
\hline Sering & 60 & 60 & 12 & 50 & 28 & 60 & 14 & 64 & 26 & 54 \\
\hline Jarang & 12 & 10 & 58 & 14 & 60 & 14 & 60 & 10 & 50 & 16 \\
\hline Tidak pernah & 4 & 10 & 20 & 0 & 10 & 10 & 20 & 2 & 18 & 2 \\
\hline
\end{tabular}

Berdasarkan tabel 5, rata-rata persentase (79\%) sikap positif mahasiswa terhadap materi diferensiasi dan integrasi numerik dan $21 \%$ mahasiswa memberikan respon sebaliknya. Sebagian besar mahasiswa merasa senang dan bersemangat untuk mengikuti 
materi diferensiasi dan integrasi numerik (78\%), menyukai materi yang diberikan (80\%), dan setuju jika materi diferensiasi numerik dan integrasi numerik dapat dipahami dengan mempelajarinya secara sungguh-sungguh $(86 \%)$. Walaupun mahasiswa menyukai materi diferensiasi dan integrasi numerik, tapi masih terasa dianggap sulit dipahami (76\%), tetapi dapat dipahami kalau mempelajarinya secara sungguh-sungguh (88\%). Dari dua materi yang diberikan, mahasiswa menganggap integrasi numerik lebih sulit daripada diferensiasi numerik $(82 \%)$.

Pernyataan negatif yang diberikan untuk menguji konsistensi pendapat mahasiswa. Mahasiswa konsisten menganggap materi yang diberikan tidak termasuk kategori sulit sekali (78\%). Pendapat para mahasiswa ini konsisten dengan pernyataan positif sebelumnya. Dalam pendapat materi yang membosankan, mahasiswa tidak selalu ingin jam materi diferensiasi dan integrasi numerik di dalam kelas segera berakhir (70\%), dan tidak ingin kalau materi diferensiasi numerik dan integrasi numerik diberikan dalam waktu yang singkat (80\%), meskipun tidak menganggap materi diferensiasi numerik dan integrasi numerik mudah dipahami $(68 \%)$.

Tabel 6. Respon Mahasiswa Soal Kemampuan Berpikir Reflektif Matematis

\begin{tabular}{lcccccccccc}
\hline \multirow{1}{*}{ Kategori } & \multicolumn{8}{c}{ Jumlah Respon terhadap Pernyataan (\%) } \\
& \multicolumn{1}{c}{} & 6 & 7 & 8 & 10 & 11 & 12 & 14 & 17 & 19 \\
\cline { 2 - 13 } & - & + & - & + & - & + & - & + & - & - \\
\hline Sangat Sering & 4 & 24 & 18 & 28 & 8 & 26 & 4 & 18 & 10 & 16 \\
\hline Sering & 12 & 60 & 24 & 60 & 30 & 50 & 32 & 56 & 12 & 20 \\
\hline Jarang & 58 & 10 & 50 & 12 & 50 & 14 & 52 & 20 & 72 & 50 \\
\hline Tidak pernah & 26 & 6 & 8 & 0 & 12 & 10 & 12 & 6 & 6 & 14 \\
\hline
\end{tabular}

Berdasarkan tabel 6, terhadap soal-soal latihan yang diberikan, mahasiswa menganggap penyajian soal latihan materi diferensiasi numerik dan integrasi numerik membantu mahasiswa memahami materi yang diberikan (73\%), mahasiswa merasa senang dapat mengerjakan soal latihan diferensiasi numerik dan integrasi numerik dengan benar $(86 \%)$, dan cenderung lebih senang mengerjakan soal dengan cara sendiri daripada melihat pekerjaan teman (88\%). Soal yang diberikan dianggap cukup menantang (74\%), dan ingin mencoba untuk menyelesaikan soal dengan cara yang berbeda $(76 \%)$.

Dalam hal menjawab dengan beragam jawaban, mahasiswa merasa kesulitan jika diminta menjawab soal dengan beragam jawaban (93\%). Untuk soal yang sulit, mahasiswa memerlukan waktu yang cukup lama (58\%), tidak merasa jenuh dalam mengerjakan soal 
yang sulit (62\%), dan merasa tidak terpaksa mengerjakan soal diferensiasi numerik dan integrasi numerik (64\%). Beberapa kendala mahasiswa dalam mengerjakan soal adalah sering keliru dalam menuliskan kembali informasi yang diketahui pada soal (78\%) dan kurang percaya diri dalam menyelesaikan soal dengan cara sendiri (78\%).

\section{KESIMPULAN}

Berdasarkan hasil penelitian yang sudah dilakukan, dapat disimpulkan:

1. Rata-rata kemampuan berpikir reflektif matematis mahasiswa calon guru pada materi diferensiasi dan integrasi numerik termasuk kategori baik

2. Rata-rata kemampuan berpikir reflektif matematis mahasiswa per indikator menunjukkan kategori sangat baik untuk dua indikator, kategori baik pada 1 indikator, dan kategori cukup pada 1 indikator

3. Sikap mahasiswa positif terhadap materi diferensiasi numerik dan integrasi numerik

\section{DAFTAR PUSTAKA}

Adam, A. (2002). Exploring the gender question in critical information systems. Journal of Information Technology, 17(2), 59-67.

Ash, S. L., \& Clayton, P. H. (2004). The articulated learning: An approach to guided reflection and assessment. Innovative Higher Education, 29(2), 137-154.

Bright, B. (2003). Reflection and knowledge: aspects and problems. Conference Proceedings, pp. 42-47.

Burden, R. L. \& Faires, J. D. (2011). Numerical Analysis $9^{\text {th }}$ Ed. Boston: Brooks/Cole Cengage Learning.

Dinkelman, T. (2000). An Inquiry Into The Development of Critical Reflection in Secondary Student Teachers. Teaching and Teacher Education, 16(2).

Dohn, N. B. (2011). On the epistemological presuppositions of reflective activities. Educational Theory, 61(6).

Kubiszyn, T dan Borich, G. D. (2003). Educational Testing and Measurement: Classroom Application and Practice, $7^{\text {th }}$ Edition. New York: Wiley.

Munir, R. (2010). Metode Numerik. Bandung: Informatika.

Takona, J. P. (2002). Pre-service Teacher Portfolio Development. Lincoln, NE: Writers Club Press.

Zeichner, K. M., \& Liston, D. P. (2010). Reflective teaching: an introduction. Mahwah, NJ: Routledge. 